\title{
Teachers should be like second parents Affectivity, schooling and poverty in Mexico
}

\author{
Blasco, Maribel
}

Document Version

Final published version

Publication date:

2002

License

CC BY-NC-ND

Citation for published version (APA):

Blasco, M. (2002). Teachers should be like second parents: Affectivity, schooling and poverty in Mexico. Paper presented at Paper presented at the conference:"Foro de Anális: La Educatión Básica en México: balance y perspectivas", organised by Revista Cero en Conducta, Mexico City 15-20 July 2002. Theme track: Secondary education in Mexico..

Link to publication in CBS Research Portal

\section{General rights}

Copyright and moral rights for the publications made accessible in the public portal are retained by the authors and/or other copyright owners and it is a condition of accessing publications that users recognise and abide by the legal requirements associated with these rights.

Take down policy

If you believe that this document breaches copyright please contact us (research.lib@cbs.dk) providing details, and we will remove access to the work immediately and investigate your claim. 
Paper presented at the conference: 'Foro de Análisis: La Educación Básica en México: balance y perspectivas', organised by Revista Cero en Conducta, Mexico City 15-20 July 2002. Theme track: Secondary education in Mexico.

\section{Summary}

The paper highlights the importance of affectivity in school retention in public secondary schools in Guadalajara, Mexico, in a socioeconomic context where the students themselves often decide whether to stay in school or to drop out. In such contexts, students' feelings towards the school and the teachers can become crucial in deciding whether to persist with school or not, especially when they are already under pressure due to economic difficulties and other family pressures. Yet currently, pressures to achieve efficiency in schools limit teachers' capacity to establish more personal contact with their students. The article looks at a space within Mexican secondaries that could potentially help attend to students' emotional well-being: the 'clinic' manned by the educational guidance counsellor (gabinete del orientador); but also points to obstacles that can prevent this space from being used in a constructive way.

By Maribel Blasco

Assistant Professor in Spanish American Studies, Department of Intercultural Communication and Management, Copenhagen Business School, Denmark

Email:mb.ikl@cbs.dk

Telephone: +4538153349 
"Teachers should be like second parents": Affectivity, schooling and poverty in Mexico.

By Maribel Blasco

\section{Introduction}

School effectiveness research has done much to nuance the rather bleak debates on the link between public schooling and poverty in Mexico. ${ }^{1}$ Research has shown that schools can make a difference: students perform best in states where school quality is highest (Palafox, Prawda and Velez, 1994), and schools offering adequate resources, effective teaching and relevant timetables and curricular content for the population they serve have proved able to combat poorer students' initial disadvantages (SNTE, 1994, p. 61; Martin, 1998a; Reimers, 2001). Other research suggests that some of the problems that undermine school performance, but that lie outside the school's usual ambit may also be preventable with the help of the school's intervention (Sanchez Escobedo and Pinto Sosa, 1995). Various compensatory programmes ${ }^{2}$ in Mexico have attempted to do just that by improving school infrastructure and quality, and providing material support for students and their families in the form of grants and school breakfasts (Ornelas, 2001). Such initiatives are designed to improve retention and performance, thus breaking the vicious circle where disadvantaged students are further handicapped by a truncated education, and fomenting equity.

Based on a study ${ }^{3}$ of a public secondary school in Guadalajara, this article focuses on a dimension that has received little attention in Mexican educational research, policy and administration, or in the design of compensatory programmes: that of affectivity. It is argued that in socioeconomically disadvantaged contexts such as that discussed here, students' affective experiences of the teachers and school can have a crucial influence on retention since schooling decisions are often left up to the students. No sanctions are applied to parents whose children fail to attend school in Mexico despite secondary having been compulsory since 1993 (see SEP 1993: 21). The students' say in schooling in poorer areas marks a key difference from contexts where schooling is compulsory in practice, i.e. where parents oblige their children to attend, as among better-off Mexican families, for instance. For Mexican public secondaries located in poorer catchment areas, a key measure of effectiveness is, therefore, whether or not they succeed in retaining students until they complete their compulsory basic education (i.e. primary and secondary). This is crucial in terms of equity goals. Secondary schooling suffers from high rates of dropout, with poorer sectors particularly severely affected, and it has become a key 'make or break' level in Mexican education both in terms of work and life opportunities and the reproduction of inequality (Reimers, 2001, p. 201). ${ }^{4}$ Little work has yet been done on the connection between schooling and poorer urban families at secondary school level in Mexico. ${ }^{5}$

Research into the schooling-poverty link in Mexico has tended to focus primarily on cognitive, economic and/or cultural factors, and measurable outcomes rather then processes, with little focus on students' subjective and affective experiences of schooling. However, the importance of emotions and caring for different educational actors has lately attracted increasing interest in a number of other contexts (Hargreaves, 2000 and 2001; Martin, 2000; Noddings 1992; Nias, 1997). Affective and academic aspects have been found to be closely linked in schools, particularly at secondary level, with closer emotional bonds between students and teachers having a positive

\footnotetext{
${ }^{1}$ See Schmelkes (1999, p. 3), Vaughan (1982, p. 4), Morales-Gómez and Torres (1990, p. 31), who offer rather damning assessments of schooling's capacity to alleviate inequality or offer the poor opportunities to improve their lives.

${ }^{2}$ For instance: PALEM, PARE, PIARE, the educational dimension of PRONASOL and PROGRESA, and educational programmes for very small communities (Martin, 1999; Martin, 2000; Ornelas, 2001).

3 The data resulted from a year's fieldwork employing ethnographic methods including: in-depth interviews with students, teachers and parents, observation, group interviews with students, and a survey of 84 students. Supplementary data was collected from surrounding secondary schools, including interviews with the school counsellors.

${ }^{4}$ In a 14-country study of Latin American education, Reimers (2001) found that a person who had completed secondary school would earn on average $120 \%$ more than someone who had never been to school. In Mexico, even the most unskilled jobs now require a secondary certificate.

${ }^{5}$ Although a sizeable body of work exists on at primary school level in Guadalajara, see Martin (et al. 1990a; 1990b; 1992; 1993a; 1993b; 1994; 1996a; 1996b; 1998a; 1998b).
} 
effect on student performance, retention and well-being (Sammons, 1999, p. 84; Hargreaves, 1998, 2000 and 2001; Martin, 2000; Ranbon, 1986). The most effective schools have been found to be those that combine 'a warm, non-discriminatory emotional environment and well trained, committed teachers with high academic expectations' (Martin, 2000, p. 7).

The paper looks at a space within Mexican secondary schools that could potentially offer affective support to students and help them to feel more positive towards the school: the gabinete del orientador, a clinic manned by a counsellor and/or social worker whose function is to provide guidance to students and to deal with problem cases channeled to them by teachers. It is currently important to take a fresh look at the work and potential of the orientador, since the orientador's specialisation, Psychology and Pedagogy, was removed from the teacher training curriculum in 2000 by federal decree, ${ }^{6}$ thus endangering the future of the gabinete in Mexican secondaries (Beltrán et al., 2002).

\section{Case and context}

The case studied is that of third year secondary school students from three marginal, urban colonias (an area referred to henceforth as 'La Colina') on Guadalajara's southernmost periphery that started life as irregular settlements in the early 1970s. Guadalajara is Mexico's second city and the capital of the state of Jalisco in central-west Mexico. The city, with around 3.5 million inhabitants, is currently the most important industrial centre in West Mexico, with a vibrant economy (De la Peña and Escobar, 1990; Ramírez, 1990; Durán and Partida, 1990; Pro Habitat, 2000, p. 3).

Although among the better-off states ${ }^{7}$ in Mexico, Jalisco and its capital, Guadalajara, are socioeconomically heterogeneous and contain sizeable 'pockets' of poverty, with rural and marginal urban areas particular severely afflicted (De la Peña and Escobar, 1990). Most of the families of students at the school studied experienced economic hardship. Of the fathers surveyed, most were employed as builders, drivers or salespeople, often subject to casual contracts. ${ }^{8}$ Few mothers engaged in paid employment. ${ }^{9}$ Economic insecurity undermined parents' ability to plan ahead and save for large outlays such as the beginning of the school year, as well as to meet the constant trickle of school-related expenses throughout the year, which parents often found it hard to meet. ${ }^{10}$

Third-year students in their final year of secondary were selected for the study, i.e. students aged 14-15 years. ${ }^{11}$ The point of selecting final year students was to gather accounts of students' school careers in order to identify the contingencies which led to dropout and/or undermined performance: i.e. the fragile moments in their schooling. The students who participated in the study were all, arguably, successes already since they had almost made it to the end of their compulsory basic education, unlike many of their peers in Mexico. ${ }^{12}$ They could thus describe

\footnotetext{
${ }_{7}^{6}$ See Diario Oficial de la Federación, SEP Acuerdo 269.

${ }^{7}$ Mexico is a federal republic. In this article, 'State' refers to the federal State, and 'state' to the regional states.

${ }^{8} 71 \%$. 4\% were professionals, and the remaining $25 \%$ worked as mechanics, electricians, handymen or cleaners. This pattern corresponds to the figures for the area from the National Statistical Institute, which asserts that in La Colina, $71 \%$ of the economically active population are employees, $40 \%$ work in the tertiary sector and $56 \%$ in the secondary sector. Around $75 \%$ of workers earn less than two minimum wages (salario mínimo) (SCINCE, 1995).

${ }^{9} 49 \%$ wroked exclusively as housewives, $13 \%$ were domestic workers and a further $5 \%$ carried out domestic work for others at home (lavar y planchar ajeno). $8 \%$ worked as labourers (obreras) or in factories. 6\% were teachers or nurses; and $12 \%$ were self-employed salespeople (selling e.g. Tupperware or homemade handicrafts) In sum, only $14 \%$ of mothers survened had regualr, paid employment with the accompanying welfare benefits and the security to plan ahead.

${ }^{10}$ The indirect costs of schooling are higher at secondary level than at any other. The Education Ministry (SEP) provides the school building and the teachers, but everything else must be funded through parents' 'voluntary' contributions. Other costs include: a set of textbooks, the uniform, transport costs, contributions and costumes and so forth for extracurricular activities and school outings,

${ }^{11}$ Secondary usually begins at age 12 and ends at age 15.

${ }^{12}$ Between 1999 and 2000 terminal efficiency rates for secondary fell from $76.2 \%$ to $73.4 \%$, and dropout rose from $8.2 \%$ to $9.3 \%$ (SEP/IMJ, 2000). Only $78 \%$ of $13-15$ year-olds are currently estimated to be enrolled in secondary schools. Terminal efficiency for primary is estimated at around 93\%, but this figure conceals differences of over $30 \%$ between the best- and worst-performing states. Around $87 \%$ of primary completers currently go on to secondary (www.sep.gob.mx).
} 
times when their own schooling or that of classmates had been in jeopardy or they had temporarily dropped out of school, later to return. ${ }^{13}$ They could also offer accounts of how they had managed to stay in school despite poverty and other difficulties.

The school was founded in 1990 at the initiative of a small group of teachers who gave classes to children in a makeshift, open-air school in the hills near La Colina. Local families had to be chivvied into sending their children to school, although there was a pressing need for a secondary in the area. ${ }^{14}$ The school soon became officially incorporated into the Public Education Ministry (SEP), and a school building was constructed a kilometre or so away from La Colina. The school had around 500 pupils at the time of the research, with classes of from 40-65 students.

\section{The school as an appealing alternative to home? Some theoretical and methodological reflections}

In critical educational literature, the school has typically been regarded as a site of alienation for students, and not as a place where they seek solace, affection or a respite from home. Structuralist accounts of schooling and poverty as well as theorists of cultural 'mismatch' and reproduction, such as Bourdieu and Passeron, Bernstein and the scholars from the Birmingham school, ${ }^{15}$ focus on various types of symbolic violence that the school supposedly does to students. Within such approaches, the home has typically been portrayed as the source of origin of students' class and cultural identities, identities that students are assumed to inherit from their parents. The resulting clashes between 'family culture' and 'school culture' are deemed detrimental to school performance (Connell, 1983, p. 227). In Bourdieu's terms, children inherit the 'wrong' kind of cultural capital from their parents, a kind that will prevent them from being able to adapt to the school.

Within such an approach, the school tends to be portrayed as the key site of cultural and generational negotiation, resistance and conflicting values, not the family. Primary socialisation in the family is depicted as a fairly harmonious process, 'ignoring the crises, resistance and discontinuities that child-rearing really encounters, the significance of intra-personal conflict, of divided motives and purposes, in shaping practice in later life' (Connell, 1983, p. 153). Applied to schooling, this type of approach leaves little room for an exploration of any positive contributions that schooling may make to students' lives, or how these might be deliberately reinforced in order to promote attendance. This type of approach focuses one-sidedly on the symbolic violence that the school supposedly exerts over students, and students' resistance to this (Connell, 1983, p. 154). Within such frameworks, it is difficult to imagine young people having a positive attitude to, or being able to adapt to, an institution whose values or linguistic, class, racial or disciplinary 'cultures' differ substantially from those at home.

Connected to this, and similarly problematic, has been the search in educational research for cognitive, cultural or material factors to explain school performance, which has meant that students' qualitative and affective experiences of school and learning have been downplayed (Hargreaves, 2000). These factors then tend to come across as detached from the students themselves, as though they existed in their own right. Students' own voices have been neglected, and the fact that academic subjects are 'containers of feelings' as well as containers of facts is often overlooked (Shaw, 1995 in Morley and Rassool, 1999, p. 126; Anderson and Herr, 1991).

In this study, students' experiences of schooling were explored using an interpretive approach drawing on the lifeworld concept of Alfred Schutz. The study did not attempt a full description of students' lifeworlds; rather, as indicated above, to understand their qualitative experiences and expectations of the school that, it is argued, are partly shaped by their home

\footnotetext{
Of the population currently aged $15-19,71.7 \%$ have not completed secondary school (Beltrán, 2002).

${ }^{13}$ Dropout in Mexico is not necessarily always definitive: students may take a year or six months off here and there owing to some family contingency such as the birth of a new child or going through a rough patch economically.

${ }^{14}$ Parents were typically reluctant to send their children to a secondary too far from home, as this both entailed daily transportation costs and all kinds of possible 'dangers' (peligros) along the way.

${ }^{15}$ E.g. Paul Willis, whose (1977) study 'Learning to Labour' is a key CCCS study on the linkages between education, class and culture.
} 
environments. The interpretive tradition seeks to understand the subjective meaning of social action, and consequently it focuses on the premises for action rather than the outcomes, and the subject's perceptions about reality are seen as shaping his/her actions (Schutz, 1972). Schutz and Luckmann (1973, p. 3) define the lifeworld as 'that province of reality which the wide-awake and normal adult simply takes for granted in the attitude of common sense'. The lifeworld is not a harmonious or coherent continuum, however, actors in the modern world must navigate between many different domains of meaning, or multiple realities, such as the home and the school, in the course of their daily lives. These multiple realities may differ substantially or even be incompatible with one another in fundamental ways.

These concepts are further refined by Berger and Luckmann, with a sharper focus on identity and a differentiation between primary and secondary socialisation. Primary socialisation is a child's initial identity formation process in the family: a person's 'base-world'. Secondary socialisation involves 'the internalisation of institutional or institution-based sub-worlds'. These subworlds constitute 'cohesive realities characterised by normative and affective as well as cognitive components' (1966, pp. 158 and 177). According to Berger and Luckmann, although there is usually a strong affective identification with the socialisers of early childhood (typically parents), during secondary socialisation 'alternative realities and identities appear as subjective options' (1966, p. 177 and p. 191). Within this framework, it is not inconceivable that institutions like the school could come to represent a viable alternative to students' home worlds in some way. In a similar vein, research on adolescence has shown how this lifestage is often marked by increasing reflexivity and autonomy, where young people start to make choices and develop views that may diverge from those of their families as they grow older and acquire other points of reference from agencies of secondary socialisation, such as the school or a circle of friends who offer a pool of alternative experiences to compare themselves with (Erikson, 1994; Muuss, 1997). This portrayal of socialisation differs substantially from that of Bourdieu, for instance, who posits that domains encountered during secondary socialisation are seen through the 'lens' of the dispositions acquired during primary socialisation. Similarly, Bernstein, for instance, sees the family - the primary socialisers - as transmitting a class identity and disciplinary codes that become the child's formative cultural influence, colouring its subsequent perceptions and receptivity to non-family contexts (Bernstein, 1977a). This logic underpins 'mismatch' approaches, where students are assumed to have a hard time adapting to school because of a clash of 'cultures', and may respond by explicitly rejecting the school by forming school 'counter-cultures'. ${ }^{16}$

Studies of Mexican secondary students do not, however, support a thesis of secondary school counter-cultures arising from a mismatch between family and school cultures and values. Rather, students have generally been found to be positive towards the school, an observation corroborated in this study (see e.g. Levinson 1993, 1997 and 1999; Blasco 1998 and 2001). ${ }^{17}$ Students saw the school both as a comparatively pleasant immediate alternative to their home environments, and as a route to a better future inasmuch as the school symbolised the hope of an escape from poverty. The home and the school are conceptualised here as the key spheres impinging on students' perceptions of the school; with the key actors within these spheres being family, teachers and friends.

This does not mean that students' views were not also shaped by influences outside these two spheres, ${ }^{18}$ however, it was found that students had little time or freedom outside school to engage in independent activities with their peers. Students had to earn the right to be in school by being dutiful and compliant at home, pulling their weight in the domestic sphere either financially

\footnotetext{
${ }^{16}$ For Bernstein (1977a; 1977b; 1982), for instance, dissonant class 'codes' relating to styles of authority are the key impediment to children's adaptation to the school; for Bourdieu (1977), these dissonances are linguistic; whilst for Bowles and Gintis (1976), the differences are gender- and race-related.

${ }^{17}$ Martin's work in Guadalajara schools and rural schools in Jalisco, although this was carried out in primary schools not secondaries, also consistently encountered a degree of enthusiasm for schooling that contrasts with experiences reported by scholars of education in the advanced industrial societies (Martin, 1994, p. 158).

${ }^{18}$ Other studies have found that global flows of commodities and images have penetrated the self-image and aspirations of young Mexicans (see e.g. Levinson, 1993; Guttman, 1996, p. 134).
} 
or by helping with domestic tasks, ${ }^{19}$ Moreover, the colonias that comprised the school catchment area are infamous both locally and throughout Guadalajara as 'dangerous' areas without a strong sense of local community that might have engendered a more distinct, autonomous local youth culture (see also Martin 1990a, p. 126-7). ${ }^{20}$ Parents' main attitude towards the world beyond their front doors when it came to their adolescent offspring was trepidation: fear that something might happen to them if they let them too far out of their sight, with the result that students enjoyed little freedom in their home environments. ${ }^{21}$

In the Mexican context, Martin (1985; $1990 \mathrm{a}$ and b, 1992, 1993a and b; 1994; 1996; 1998a and b; 1999, see also Guzmán and Martin, 1997) is one of the few researchers who has brought students' experiences of the school and home into the educational picture in a more holistic way, looking at the affective climate in the home and the 'moral economy' of the domestic unit and how these influence primary schooling. Martin found that the key relationship affecting primary school retention was that linking 'teachers with their clients (the parents and their children)' (1998, p. 167). He calls this the relationship of educational provision. ${ }^{22}$ Martin stresses the importance of the parent-teacher relationship since he found that at primary level it is parents who take the key decisions regarding their children's schooling (Martin, 1998b, p. 177; Martin, 1996). ${ }^{23}$ If parents experience friction with teachers, their children's schooling may well be jeopardised.

Although many of Martin's findings are also applicable to the secondary-school context, the pivotal nature of the parent-teacher link for school retention is arguably a key area where secondary differs from primary, with important consequences for explaining secondary school performance among poorer sectors. La Colina parents were often remarkably passive when it came to deciding whether their children would stay in school or not, often leaving the decision up to the students themselves. The students' say in schooling has largely been overlooked in the literature on Mexican basic education precisely because it is usually assumed that parents make the decisions, i.e. that what holds true for primary schooling is also applicable to secondary (see also Sandóval, 1993, p. 6).

Yet at La Colina students indicated that they had decided to continue studying despite the indifference or even opposition of their parents; and also many reports of students who had dropped out of their own accord or because of inertia and lack of encouragement on the part of their parents. There was scant parental pressure on them to continue with their studies. Students frequently told of friends who had dropped out of school on apparently very flimsy pretexts such as 'a problem with a teacher', 'social problems' with other students, or because they had suffered minor illnesses and simply failed to go back when they got better. Motives for dropout included a student who became frightened after having been at school during an earth tremor; and

\footnotetext{
${ }^{19}$ Both boys and girls wrote in the questionnaire that they helped out regularly with all kinds of housework and childcare of younger siblings. Students' (especially girls') free time was very much restricted to the home: reading, watching television or listening to music or the radio; or they would participate in extra-curricular school activities such as dancing or singing practice; or catechismo, religious teaching to younger children at the local Catholic church. Boys were less home-bound: most played football or some other type of sport, and more boys than girls had paid jobs (42\% compared to $21 \%$ of girls).

${ }^{20}$ Rosas (2000), in her study of social networks in poor urban areas in Mexico, indicates that suspicion of neighbours and fear of neighbourhood problems such as drug addiction and delinquency, had led to a 'climate of distrust' and the increasing retreat of families into their homes. Mothers fear especially for their children, as many families have members who have experienced drug addiction.

${ }^{21}$ In her study of youth in New York and rural Sudan, Katz (1998, p. 135-6) found, similarly, that 'in the absence of safe, outdoor spaces, young people become prisoners of their homes, often isolated with only the television or worse for companionship. The restricted access to the public environment, and with it many opportunities for forging and negotiating peer culture ... is generally worse for girls than for boys'.

22 He locates the main problems in this relationship in, at one level, declining funding in schools and deterioriating conditions for teachers and, at another, 'insecurities in the household reproduction of the clients' (Martin, 1998, p. 167). The parent-teacher relationship usually takes the form of practical demands made by the school on children and parents, such as homework and periodic expenditures connected with schooling.

${ }^{23}$ Findings from the World Bank (1999, p. 48) assume the same, adding secondary schooling to the equation: 'it is typically parents who make the decisions about education (especially primary and secondary education) for their children - not the children themselves'.
} 
another who 'cut his finger' and failed to return to school. Other teachers confirmed that students often dropped out because they 'just didn't feel like studying any more'. ${ }^{24}$ Because it is often left up to the students to decide whether to persevere with their studies or not, their feelings towards the school and their relationships to teachers can have a decisive impact on school retention.

\section{Defining affectivity in relation to schooling}

"I think that in general there's a need for a more personal treatment by teachers. As it is, they just walk into the classroom, give you instructions and this and that, when really they should be like students' second parents ... because you spend half your life in school and you always need some teachers to give you more support".

This remark by a fourteen-year old student was typical of students' descriptions about their relationships with their teachers in the secondary school studied. Students placed a great deal of importance on teachers' affective manner towards them. They responded better academically and in terms of discipline to teachers who took an interest in them as people, and treated them as feeling, complete human beings, and did not related exclusively to their 'academic' side. ${ }^{25}$ Around a quarter of students surveyed indicated that the teachers were what they liked best about the school, praising those who were 'understanding' (comprensivos), relaxed, nice and a good laugh (suaves, buena onda). Over three-quarters of all students wrote that they liked a particular teacher and his or her class best because s/he talked or listened to them (platica con nosotros, nos escucha); acted as a friend towards them (se porta como amigo); offered them moral support (es comprensivo, me entiende); or simply that there was good communication between them (hay buena comunicación). When asked why they went to school, ${ }^{26}$ students often claimed that they went to school to 'get things off their chests', 'to talk', or even 'to get away from home'.

These types of 'feelings' are broadly conceptualised in the paper under the term affectivity defined as a student's emotional susceptibility. Affectivity is used to convey a broader sense of a student's subjective emotional well-being than 'emotions', which are understood as particular types of mental feeling or affection (e.g. pleasure or pain, desire or aversion, surprise, hope or fear, etc. $)^{27}$ The term affectivity is used in conjunction with the concept of the 'affective climate' prevailing in the school, i.e. its affective atmosphere or 'feel'. Three key dimensions, described below, are seen as shaping the affective climate in the school and students' expectations of it.

\section{i) School disciplinary structure and style}

The first dimension is the school's formal disciplinary structures. The SEP provides disciplinary guidelines for secondary schools that may then be adapted at school level. These guidelines list standard disciplinary expectations as well as misdemeanours and their corresponding sanctions. In addition, La Colina had its own official sanctions system, based on the SEP guidelines. However, recognising that many students came from undisciplined home backgrounds, often had heavy domestic or work commitments, and often could not afford to buy the correct equipment for school, La Colina teachers claimed that the school had introduced an informal policy of leniency when applying the school rules.

\footnotetext{
${ }^{24}$ Although it is impossible to be sure that this was the real reason for their dropout. I consulted with teachers about the number of bajas (students who had left the school) over the previous couple of years. The reasons for bajas are difficult to ascertain, since records are not kept about why students leave school. Someone who moves house is reported in exactly the same way in SEP records as someone who drops out because of family problems. However, teachers were able to remember and tell me the reasons why some students had left.

${ }^{25}$ In this connection, Freire's 'banking concept' of education (1994, p. 72) contains a powerful critique of a narrow focus on information transfer whilst neglecting other aspects of the student which may affect his or her capacity to learn'. He recommends compañerismo between teachers and students, as well as the need to socialise together, get to know one another ... and communicate (convivir, simpatizar ... comunicarse)'.

${ }^{26}$ In group interviews, a questionnaire and informal conversations.

${ }^{27}$ Following the Oxford English dictionary definition.
} 
Thus, for instance, teachers claimed that they would often turn a blind eye to students who turned up late, or with bits of their uniforms missing or the wrong style or colour. The school had also introduced several schemes in an attempt to soften the school disciplinary climate and adapt it to what were seen as the special needs of its unruly students. One of these was what teachers called the classroom-workshop system (aula-taller), where each teacher had his or her own fixed classroom and the students moved around between classrooms, instead of teachers going to the students as is usual in Mexican secondaries. This was done to give restless students a chance to stretch their legs between classes and let off steam. In the same innovative spirit, La Colina teachers had obtained the permission of the zonal inspector to 'experiment' with continuous assessment instead of applying the frequent exams students sat in other secondaries. This measure was taken since it was felt that students would not respond well to the pressure and discipline of enforced examinations.

In practice, however, these schemes were left very much to the discretion of the individual teacher. For instance, filed school disciplinary reports (reportes) ${ }^{28}$ and the researcher's own observation showed that students were, in fact, frequently reported, singled out and reprimanded or even sent home because of faulty uniforms or late arrival. Teachers acknowledged that their innovations were difficult to implement consistently, and that the school faced both internal and external constraints when trying to operate differently. Internally, not all teachers followed the school principle of leniency, and there were obvious problems of enforcement since teachers work unmonitored in their classrooms. Externally, too, the school faced academic pressures. Poor performances in several inter-zone academic competitions had sparked a heated controversy among staff about low standards, with the result that formal examinations were reintroduced.

Moreover, although teachers declared their willingness to make allowances for students' home backgrounds, this concession to leniency seemed to be undermined by their perceptions of adolescence as a difficult, unruly life stage requiring a firm hand. In Mexico, discipline at secondary level is typically far stricter than at primary or post-secondary levels (see also Levinson, 1999). Teachers described adolescence as a problem, a stage characterised by unpredictability, rebellion and confusion:

$>$ Psychologically and physiologically adolescence is one of the most difficult stages ... The kids are rebellious and refuse to do what we tell them to, they don't let anyone give them advice or tell them off ...

$>$ Secondary is the age when kids are very difficult, very conflictive, so they represent a real danger, they're not controlled or controllable

$>$ Adolescents are very prone to ignoring authority ... it's not just all about talking and being reasonable, because there comes a time when that doesn't work any more and you have to use repression because if not, you lose your authority which is what should always prevail.

Students' reactions to the disciplinary style at La Colina were mixed. They were not opposed to discipline per se, on the contrary, they responded well to teachers who maintained order in the classroom, as long as they combined this with fairness, sympathy and respect for students. The survey revealed that $51 \%$ of students also got the best marks in subjects taught by their favourite teacher, with typical examples of why students liked a particular teacher including:

$>$ He's not so much like a teacher but a friend to us.

$>$ He knows how to listen to us students.

> She always listens to my problems, she gives me advice and I like her classes: there is good communication between us.

$>$ She listens to everything we tell her, our worries and all that, and she helps us to

\footnotetext{
${ }^{28}$ Reportes must be signed by parents; three reportes is grounds for expulsion.
} 
solve our problems.

Conversely, students disliked and resented teachers who were inconsiderate, disrespectful, or 'despotic' (déspotas) towards them, and they regretted the impersonal nature of their contact with many of them:

$>$ A few of the teachers talk to you but the others don't care ... I've seen teachers who don't respect the students

$>$ The teacher doesn't understand us and doesn't pay us any attention ... there are lots of injustices

$>$ If my grades fail, the teachers put pressure on me, they don't say "come here, l'll explain it to you", they say "you've got to pull up your grades somehow, but it's up to you to find out how"

Students also bitterly resented disciplinary procedures that they regarded as petty or unreasonable, such as stringent rules regarding uniform and appearance, or being denied what they saw as their basic 'rights':

We like discipline, but up to a point, they shouldn't take away our rights ... like going to the toilet ... they don't let us ... one thing is when we don't do what we're told and another is that they aren't fair towards us.

Students told of classmates who had dropped out becasue of quarrels with teachers (problemas con un maestro); being told off (regañado) or simply because of lack of affection (falta de cariño). One girl remarked that she had actually stopped going to classes at another school because she felt that the teachers were indifferent to her:

In the school where I was before, the teachers didn't pay us any attention, so we didn't listen to them either, I ddin't leave that school but I just never went to classes and that affected me very badly, I failed my second year.

Similarly, another girl told how in her second year at secondary school she had stopped going to one class because she felt the teacher treated her unfairly:

When I began my second year, I had a teacher, my God, a real witch! Always having a go at us. She whacked me because I had a classmate called Susana who was terrible, I never used to talk in class but she was "yap yap yap" all the time, and suddenly the teacher came up behind me, and slap! She whacked me on my back. I just cried for the rest of the class and after that I was scared to go back, after that I never went to her classes any more, never.

The importance that students attach to contact with teachers is also evident from reports of difficulties experienced by students during the transition from primary to the more impersonal and strictly disciplined secondary school (see also Rockwell, 1990; Blasco, 1998). The difficulties students experience during this transition may be one reason why dropout rates at secondary are highest in the first year. At primary school, students have one teacher for all their classes, and are able to develop a closer relationship to him or her. At secondary, conversely, students can have as many as eight different teachers each day. Classes last a mere fifty minutes, and time for more personal interaction is very limited. One girl explained that adapting to the new, more distant relationship with her teachers was very hard for her as a first-year student, and that she had dreaded it before starting secondary:

Uuuu, well the only image we all had here was that we were going to change 
teachers, we'd have different teachers, yes, we all thought that would be difficult, we used to say 'Ay, a different teacher every hour!' Here at primary school we only have one ...I mean, we did have the idea that we'd be learning more but we always used to say 'Oh, why do we have to have so many teachers? We won't cope? And I even swore that I wouldn't be able to put up with so many teachers.

The above responses show how much importance students attach to contact with and a gentler, more personal touch from teachers, something which clearly also facilitates learning. Treatment meted out by a teacher which is perceived as harsh, arbitrary or unfair may suffice to push a hardpressed student over the brink towards dropout, especially if s/he is having a tough time staying in school in the first place because of lack of parental support or financial difficulties.

\section{ii) The conditions for interaction between teachers and students}

The second dimension of the affective climate in the school involves the institutional conditions for interaction between teachers and students. It was found that teachers did not deliberately shun more personal contact with students, and many acknowledged that such contact was important, particularly among students from a social context like La Colina. But especially since the 1993 reform, teachers have seen their workload grow: they have to teach a much denser curriculum and to carry out weightier administrative and assessment tasks than before (Quiroz, 1990 and 1995). The 1993 Education Reform modified the curriculum and made it denser by introducing individual subjects that had previously been integrated under a single heading, and delegating to teachers the responsibility for curricular implementation and its adaptation to local circumstances (Martin, 1998b; Quiroz, 1990 and 1995; Rockwell, 1990). ${ }^{29}$ Administrative tasks intended to sharpen teacher accountability, such as daily lesson plans that teachers must prepare, added to the pressure (see also Calvo, 1998; 9). A further worry for teachers is that their own professional performance is measured partly according to their students' grades. Large class sizes also greatly curtail teachers' capacity to get to know their students. Furthermore, teachers were often obliged to carry out extra duties such as cleaning or working in the school tuck-shop (cooperativa); and union activities ate up much of their time (see also Rockwell, 1990; Calvo, 1998). Several teachers also worked second shifts in different schools to help make ends meet.

So although many teachers acknowledged the need for greater personal contact with their students, they worried continually about their students' and their own performance and as a result the intrusion of students' personal matters was seen as undermining the pressing academic tasks at hand (see also Schmelkes, 1992; Quiroz, 1992, p. 95; Rockwell, 1990, p. 21). As one girl put it: 'with the teachers it's like "leave your problems at home, concentrate on your work", they hear me but they don't listen, they don't really know what I'm saying'. Teachers described their working days as extremely stressed:

We have to find an outlet for all the pressure of having all those students ... I work a 42-hour week, and of those 42 hours I spend 35 in class, which is the maximum I'm allowed to do, that's seven groups, seven hours a day, five days a week, seven times five equals 35 , and the remaining seven hours are for preparation, research and extracurricular activities (cocurriculares) ... I go to bed every day at two in the morning because I'm preparing classes, and then we have to fill in these forms called 'daily lesson plans' for the next day ...

As the above quote shows, teachers' busy professional lives also often encroached upon their personal lives, to the extent that several teachers described teaching as an 'apostolate' involving heavy sacrifices: 'pure giving and no receiving', as one expressed it. The science teacher, a

\footnotetext{
${ }^{29}$ Subject areas, e.g. Natural Sciences, were divided into separate subjects (asignaturas): Physics, Chemistry and Biology. This increased the number of classes taught by each teacher, multiplying the hours spent on preparation, evaluation and administration.
} 
mother of two, explained how she felt she neglected her own children because she devoted so much energy to her job:

Teachers' children are the most neglected of all. My children are having problems right now because of that. You get home tired from school, giving, giving, giving all day long, and I'm much stricter with them than I am with the kids here [at school] ... it's a job that requires commitment, it's a great responsibility ... I'm always here in the evenings and my husband says 'but how is it possible - in no other job do they expect you to work extra hours without pay'. They don't understand.

Under such circumstances, teachers hiad little suirpiuis energy to give more personal attention to students, and they knew very little about 'ineir students' home lives unless they made a point of taking a special interest. 'If I don't care, i can leave my group to its own devices, and let them solve their problems as best they can', as one teacher put it. Under such circumstances, it would be wrong to assume that teachers riaturally combine their academic tasks with a caring approach, as is sometimes supposed (Hart, 1996). Rather, caring becomes a personal choice. The net effect of this on students is that they often experienced the relationship with teachers as disappointingly impersonal. Yet a teacher's encouragement or lack of it can make or break a child's attitude to schooling (see also LeVine, 1993).

\section{iii) Affective relations in the family and students' expectations of the school}

The third dimension that was found to have ani impari on students' expectations of the school was their affective relationships and the environiment at home. Few students seemed to enjoy close relationships with their parents, and many claimed that they couldn't concentrate on their lessons because they faced tense or difficult home situations. Alcoholism, beatings and verbal abuse were not uncommon, and many students reported receiving little support for their schooling from one or both of their parents. ${ }^{30}$ Moreover, although the proportion of marital break-up was not particularly high in the school catchment area, ${ }^{31}$ many students reported difficulties between their parents that made them anxious. As one girl said, this anxiety cannot be contained; it inevitably spills over into their time at school:

One day I was crying because my Dad hit my Mum, I couldn't help it and just burst out crying and I didn't want to tell anyone - they [the teachers] hear me, but they don't really listen.

Students asserted that they liked the secondary school because there they 'forgot about [their] problems for a while' (quizás porque me olvido un poco de mis problemas), as one girl put it. Another pointed out that 'at school I can forget about home' (me distraigo de mi casa). During an informal group interview in the school playground, students had this to say:

Blanca: At home l've got a lot of problems, and here there are fewer and there's a lot of companionship: you can share your opinions with the others and they give you theirs, but at home I don't feel good

Luz: I feel a lot happier here because at home my parents are always arguing, and

\footnotetext{
${ }^{30}$ Other research has also found that physical abuse and alcoholism and its ramifications can wreak havoc on children's schooling (González de la Rocha et al., 1990; Martin, 1994).

${ }^{31}$ Of the 84 students surveyed, (85\%) lived with their biological fathers, $81(96 \%)$ with their biological mothers, and 68 $(81 \%)$ with both biological parents. Broken homes and/or single parenthood are cited both in the literature (CEPAL, 1994, p. 24) and by teachers at the school as key reasons for school failure and dropout. The assumption that family set-ups like these are problematic per se can lead us to overlook the gravity and type of problems that occur within supposedly conventional, family arrangements, and their impact on schooling. Couples experiencing tension may not separate or divorce (particularly in a cultural context like Mexico where divorce is still considered a failure (fracaso) in some sectors), but parents may nonetheless still be terribly unhappy together and this will inevitably have an impact on their children.
} 
so are my brothers and sisters and it's better here because we can get things off our chests a bit and forget about the problems at home

Many students received little support for their schooling from either or one of their parents. Most La Colina parents had only been to primary school and many had not completed that, so few were in a position to help their children with their homework and still less to understand their secondary school experiences. The students interpreted this as lack of interest in their studies on the part of their parents, and were discouraged by it. For instance, one student told how nobody at home encouraged her with her schoolwork, and she compared her mother's attitude with a friend's mother:

I go to my friend's house every day, and her mother asks her how her day went, and says to her 'So how are you going to do it then, can I help you with anything?' But when I get home and call out 'I'm back' sometimes my mum doesn't even answer me, and she's never asked 'Have you done your homework' or anything - well, sometimes she does, but only when she's annoyed ... then if she sees me with a book she goes 'Get up you lazy cow, do this, do that!' Only once she said to me 'you can study, make a bit more effort' ... but it's very rare that she says that. She's never said to me 'Let's have a look at your exercise books' or 'how's your best friend and your other mates?'

Some fathers even attempted to dissuade their children from attending school, or made it impossible for them to concentrate on their schoolwork. Blanca's father often tried to sabotage her studies:

If I say to my father 'I'm going to study', he starts to say "'why bother studying, you're never going to make anything of yourself anyway!', he always tried to discourage me ... For example, if I'm doing my homework, he makes me do something else, even if he can see that I'm busy - he forces me to get up and I feel very stressed ...

In general, mothers were more concerned that their children should study, but some were scared to actively support their schooling when this meant opposing their husbands. Female students faced negative parental attitudes towards their schooling more often than male students. Some parents didn't see the point in sending their daughters to school since they presumed that as they would only get married later, their schooling was a wasted investment and would never be used anyway (see also Levine, 1993).

Students who live in this type of family environment, in addition to the normal dose of effort they have to put into their schoolwork, also need tremendous commitment and persistence, enough not only to stand firm in the face of parental inertia, but sometimes also deliberate attempts to sabotage their studies. Given the fragility of the link between the student and the school, any disappointment or problem stemming from the school side of the equation, however trivial it may appear, can become the last straw.

\section{Rethinking the school's functions: the potential role of the gabinete del orientador ${ }^{32}$}

\footnotetext{
${ }^{32}$ The data in this section is based on interviews with the orientador from La Colina secondary school, as well as from 3 neighbouring secondaries. The data was also discussed with other orientadores and analysts at the Forum for Analisis of Basic Education (Foro de Análisis: La Educación Básica en México: Balance y Perspectivas), Mexico City, 15-20 July 2002, organised by the Mexican educational journal Cero en Conducta. I am also extremely grateful to Samuel Cielos, of the Escuela Normal Superior de México, who gave me a valuable opportunity to discuss these findings with normalista colleagues and trainee teachers; and provided me with documentation concerning the secondary school teacher training curriculum.
} 
In view of the constraints described above, it hardly seems feasible to leave the task of improving the school's affective climate up to the teachers alone. A space does exist in secondary schools, however, that could attend to students' affective needs: the clinic (gabinete) manned by the school counsellor (orientador). This service has existed since 1954 with the aim of contributing to adolescent development and providing vocational guidance. However, it is currently under threat owing to the suppression of the Psychology and Pedagogy courses in secondary teacher training schools that are required for specialisation as an orientador according to the Manual for Secondary School Organisation published by the Education Ministry in 2000 (Beltrán et al., 2002). The risk is that the gabinetes will either slowly be phased out, or instead be run by teachers of other subjects with no special training, as in fact is already often the case (Beltrán et al., 2002).

The orientador usually works daily at each secondary school in the gabinete, which is in theory open to students whenever they want to pop in. Orientadores sometimes work together with a social worker and/or a doctor where funding allows. The functions of the orientador are, broadly: to act as the last arbiter in cases where students have serious disciplinary problem and are in danger of being expelled; to attend to students' minor health and personal problems; and to make home visits in cases where students drop out, or where there are serious family problems that are jeopardising the child's school attendance and/or performance. Yet despite the fact that attending to students' affective needs is part of the orientador's mandate, in practice the orientadores often have limited powers to make a difference to students'well-being. Several factors intervene here.

First, orientadores felt that they had a low status compared to other secondary-school teachers. Although since 1999, part of the orientador's task in secondaries has been to teach a subject called Civic Education (Formación Cívica), ${ }^{33}$ orientadores have a 'soft', non-academic image that ranks them low in the school academic hierarchy. Their relatively light teaching load and the time they spent in the gabinete caused resentment among the other teachers. Orientadores reported that other teachers perceived them as 'doing nothing, just sitting in my office all day'. As a result, they were seen as 'available' to be used as school 'dogsbodies' for whatever errands needed running; or to cover for absent teachers:

We've had to fight hard to gain some respect (from the teachers) ... for example, I might be seeing to someone, or talking to a parent, but something comes up and they prefer to get me to do it than take a teacher out of his classroom. It's true that they give the other teachers more importance, a lot more.

Apart from rousing their indignation, this also meant that they were not available as they should be for students to visit them whenever they needed to. School organisation does not help in this respect. Students are not free to visit the orientador when they need to. One orientador explained how this interfered with his work, sometimes with very serious implications:

There have been times when girls have come to see me saying 'I've come to say goodbye', and I say 'That's nice, so you're moving home?' and they say 'No, I'm going to kill myself tonight', but the prefects ${ }^{34}$ are pacing up and down outside my office going 'Come on, hurry up, you've had long enough, go back to your classroom', putting pressure on us and making me nervous.

\footnotetext{
${ }^{33}$ Prior to 1999, orientadors taught a subject called Educational Guidance (Orientación Educativa), which was introduced as a taught subject for third-year secondary students as part of the 1993 Education Reform. The subject was taught by the orientador in addition to running the gabinete, and was still being taught at the time of my fieldwork in 1995-6. Much of the subejct's content has been transferred the subject Civic Education (Formación Cívica) that covers many of the same topics: careers guidance, information on civic rights and obligations, adolescent health and development and sex education (SEP, 1993b; www.sep.gov.mx).

${ }^{34}$ Prefects are specially appointed in schools to enforce discipline. They are usually studying to be teachers and work in a school at the same time to acquire experience.
} 
A further problem is that orientadores are typically assigned the task of punishing children who teachers cannot deal with. Children are 'channelled' to the orientador by teachers because of 'behavioural problems, low grades or erratic attendance', as La Colina's orientador explained. The students rarely visited her of their own accord: they were almost always sent there in disgrace (see also the survey on students' perceptions of orientadores in 24 Mexico City schools, reported in Beltrán, 2002, p. 24). In this way, students learn to regard the orientador as someone who punishes, and not as someone to confide in. From the point of view of the other teachers, the orientador's function is not to improve the students' well-being, but rather to 'sort out' the troublemakers as fast as possible so that they stop disrupting the class, and so that their grades improve. Orientadores are expected to send them back to the classroom as reformed characters:

Sometimes, the headmistress, the deputy head, the teachers, they think that just by sending the student to the gabinete he will change for the better, as though we had a magic wand. They say 'I sent him to orientación, so he must change!' But he doesn't, so they say 'You don't do a thing - I sent him to you and he's just the same as ever!'

The orientadores interviewed claimed that that they rarely got to see the students with real problems, as they tended to be withdrawn and quiet: i.e. not the classroom troublemakers.

Third, like the other teachers, every orientador approaches his or her task differently: there is no common policy on how to relate to the students. Some of the orientadores interviewed saw their function as mainly repressive or punitive:

Adolescents are very prone to ignoring authority ... it's not just about talking and being understanding, because the moment comes when that doesn't work any more and you have to resort to repression because if not you lose your authority, and that's what should always prevail.

Others did not respect the students' privacy, reporting back to teachers on what students had told them in confidence. As one girl said: 'sometimes we come to school thinking about problems at home that we can't talk to our parents about, so I think it's important that there's someone there you can confide in, talk to ... the problem is that sometimes you tell the orientadora something and she tells the headmistress, who tells the secretary'.

In this way, the school's hierarchical organisation and academic imperatives crowd out affective matters, although it is clearly highly improbable that a worried or upset child will be able to concentrate on her studies. More seriously, since students with 'behavioural problems' or low grades often come from the worst-off families, or broken homes, they are the ones who usually end up being 'punished' by a visit to the orientador. In this way, poverty and social problems are, indirectly, stigmatised and attributed to an individual failing on the part of the child. From the other teachers' point of view, the orientador's task is not so much geared towards helping the child to feel better, but rather to 'sorting him out' as fast as possible so that he doesn't continue to disrupt the class or get low marks which cause problems for his teachers. Orientadores thus face a number of constraints that prevent them from fulfilling a more pastoral role towards their students (see also Murgatroyd 1977). Their 'punitive' function alienates students and prevents them from seeing the orientador as a non-judgemental confidante.

\section{The pros and cons of the 'affective school'}

Approaches that place too much emphasis on caring for disadvantaged students in school have been criticised for confusing long- and short-term educational objectives by turning the school into a form of immediate escapism for students and obscuring the fact that effective academic learning is the only way they will be able to overcome their disadvantage in the long term (Hargreaves, 2000 , p. 3). Others have criticised the view that schools will function better if they resemble 'surrogate homes' for overlooking the risk that this is merely a kinder, gentler way of exercising more effective ideological manipulation over students (Thompson, 1997, pp. 338-9). According to 
Bourdieu (1977, p. 17), for instance: 'To overwhelm one's pupils with affection ... is to gain possession of that subtle instrument of repression, the withdrawal of affection, a pedagogic technique which is no less arbitrary ... than corporal punishment or disgrace'. There is also often an implicit or explicit assumption that affectivity is the province of the family and that it should not be allowed to 'spill over' into the school's functions (Stigler, 1991). ${ }^{35}$ As seen above, however, this clearly cannot be taken for granted among sectors such as that studied here.

However, the key issue at stake is that students continue their studies, something that cannot yet be taken for granted among poorer sectors in Mexico. The issue of whether through exercising a more affective approach the school strengthens its ideological hold over students becomes irrelevant for all practical purposes in a context where, for the students, completing their secondary is all-important in terms of their life opportunities. As illustrated above, students place great importance on their relationships with their teachers, to the point that a breakdown in communication, an unkind remark or a perceived injustice can suffice to snap the fragile link between students and the school. There is currently little awareness among teachers of just how important this is, however, and those that do realise rarely find the time or energy to act on it. They are often under too many constraints to be able to change their behaviour in any significant way. Teachers' affective style towards students therefore inevitably becomes a matter of individual style or choice, not part of an intentional and institutionalised pedagogical strategy (see also Hargreaves 2000, p. 3).

\section{Conclusions}

A key gauge of effectivity in schools serving socioeconomically disadvantaged populations in Mexico is whether they succeed in retaining their students. The article proposes that the affective climate in the school can be a decisive factor in school retention in such contexts, where school attendance is not enforced by parents and schooling decisions are often left up to the students. Affectivity is certainly not a substitute for competent, well-trained teachers and a reasonably pleasant and well-equipped physical school environment are also crucial. However, it is an important complementary dimension that has so far received comparatively little attention, and which is at risk of being overlooked in the increasingly zealous pursuit of educational 'efficiency'. It is proposed that schools could strengthen their appeal to students, and thereby promote attendance, by consciously seeking to foster a more congenial affective climate.

The following proposals include ways in which the affective climate in schools might be improved in order to promote more effective retention:

- Due to their heavy workloads and other institutional constraints, teachers are often not in a position to devote extra time to their students' affective needs. Instead, a more relaxed disciplinary style and a more sympathetic approach to students could be integrated into a more coherent 'policy' at school level and made part of everyday teaching practices. Both teacher training at the Escuelas Normales and ongoing professional training courses could raise teachers' awareness about the role played by affectivity in school retention. In this respect, it is important that structural constraints on schools' attempts to innovate should be reduced, with a pressing need for greater pedagogical autonomy for individual schools (Martin, 2000).

- Measures could be designed to draw on the companionship and mutual support that already exists among students, e.g. through the formation of informal discussion groups about school and family issues and/or organising 'early warning' systems whereby students know to alert teachers if they suspect a classmate is in danger of dropping out.

- A pressing task for future research is to reassess the role played by the orientador's gabinete in Mexican secondaries. It is important that schools acknowledge and reinforce the gabinete's potential role as a space for students to 'get things off their chests' (Blasco 1998), instead of representing, as it currently does in some schools, a space of 'punishment' mainly resorted to

\footnotetext{
${ }^{35}$ Stigler argues that the school should not attempt to replace family functions, owing to the risks implied in assuming that 'the basic goals of schools and families are similar, so that functions taken over by one no longer have to be performed by the other'.
} 
by teachers.

\section{References}

ANDERSON, G. and HERR, K. (1991) La historia oral como método para dar poder a los alumnos: ¿Qué indica su propia voz?, in: RUEDA, M. \& CAMPOS, M. (Eds) Investigación Etnográfica en Educación (México/CISE, Universidad Nacional Autónoma de México).

BELTRAN, M.L. (Ed.) Propuesta Curricular: Licenciatura en psicología educativa con formación terminal en orientación educativa, Colegio de Profesores de Psicología Educativa, Escuela Normal Superior de México (México: ENSM).

BERGER, P. and LUCKMANN, T. (1966) The Social Construction of Reality (London, Penguin Books).

BERNSTEIN, B. (1977a) Social class, language and socialisation, in: KARABEL, J. \& HALSEY, A.H. (Eds) Power and Ideology in Education (New York, Oxford University Press).

BERNSTEIN, B. (1977b) Class and pedagogies: visible and invisible, in: KARABEL, J. \& HALSEY, A.H. (Eds) Power and Ideology in Education (New York, Oxford University Press).

BERNSTEIN, B. (1982) Codes, modalities and the process of cultural reproduction: a model, in: APPLE, M. (Ed.) Cultural and Economic Reproduction in Education (London, Routledge and Kegan Paul).

BLASCO, M. (1998) "Getting things off our chests": student perceptions of secondary schooling in Guadalajara, in BUCHERT, L. (Ed.) Education Reform in the South in the 1990s (Paris, UNESCO).

BLASCO, M. (2001) In loco parentis? Students, families and secondary schooling in urban Mexico, $\mathrm{PhD}$ dissertation, Department of International Development Studies, Roskilde University, Denmark.

BOURDIEU, P. and PASSERON, J.C. (1977/1994) Reproduction in Education, Society and Culture (London, Sage).

BOWLES, S. and GINTIS, H. (1976) Schooling in Capitalist America (New York, Basic Books).

CALVO, B. (1998) The policy of modernisation of education, in: ZOU, Y. \& TRUEBA, H. (Eds) Ethnic Identity and Power: Cultural Contexts of Political Action in School and Society (Albany, State University of New York).

CEPAL (1994) El perfil de la familia, Revista Psicología, 23, September-October, pp.19-32.

CONNELL, R.W. (1983) Which Way Is Up? (Sydney, George Allen and Unwin).

DE LA PEÑA, G. and ESCOBAR, A. (1990) Introducción, in: DE LA PEÑA, G., DURAN, J.M., ESCOBAR, A. \& GARCIA DE ALBA, J. (Eds) Crisis, Conflicto y Sobrevivencia: Estudios sobre la Sociedad Urbana en México (Guadalajara, Universidad de Guadalajara/Centro de Investigaciones y Estudios Superiores en Antropología Social (CIESAS)).

DURAN, J.M. and PARTIDA, R. (1990) Industria y fuerza de trabajo. El caso de El Salto, Jalisco, in: DE LA PEÑA, G., DURAN, J.M., ESCOBAR, A. \& GARCIA DE ALBA, J. (Eds) Crisis, Conflicto y Sobrevivencia: Estudios sobre la Sociedad Urbana en México (Guadalajara, Universidad de Guadalajara/Centro de Investigaciones y Estudios Superiores en Antropología Social (CIESAS)).

ERIKSON, E. (1968/1994) Identity, Youth and Crisis (New York, Norton).

FREIRE, P. (1970/1994) Pedagogía del Oprimido (Mexico, Siglo Veintiuno Editores).

GONZALEZ DE LA ROCHA, M., ESCOBAR, A., and MARTINEZ, M. (1990) Estrategias versus conflicto: reflexiones para el estudio del grupo doméstico en época de crisis, in: DE LA PEÑA, G., DURAN, J.M., ESCOBAR, A. \& GARCIA DE ALBA, J. (Eds) Crisis, Conflicto y Sobrevivencia: Estudios sobre la Sociedad Urbana en México (Guadalajara, Universidad de Guadalajara/Centro de Investigaciones y Estudios Superiores en Antropología Social (CIESAS)).

GUTTMAN, M. (1996) The Meanings of Macho (London, University of California Press). 
GUZMAN, E. and MARTIN, C.J. (1997) Back to basics Mexican-style: radical Catholicism and survival on the margins, Bulletin of Latin American Research, 16, 3, pp. 351-366.

HARGREAVES, A. (1998) The emotional practice of teaching, Teaching and Teacher Education 14, 8, pp.835-854.

HARGREAVES, A. (2000) Mixed emotions: teachers perceptions of their interactions with students, Teaching and Teacher Education, 16, 8, November, pp. 811-826.

HARGREAVES, A. (2001) The emotional geographies of teachers relations with colleagues, International Journal of Educational Research, 35, 5, pp. 503-527.

HART, N. (1996) The role of the tutor in a college of further education, British Journal of Guidance and Counselling, 24, 1, pp. 83-97.

KATZ, C. (1998) Disintegrating developments: global economic restructuring and the eroding of ecologies of youth, in: SKELTON, T. and VALENTINE, G. (Eds) Cool Places: Geographies of Youth Cultures (London, Routledge).

LEVINE, S. with SUNDERLAND CORREA, C. (1993) Dolor y Alegría: Women and Social Change in Urban Mexico (Madison, University of Wisconsin Press).

LEVINSON, B. (1993) "Todos somos iguales": cultural production and social difference at a Mexican Secondary School, PhD dissertation (Department of Anthropology, University of North Carolina).

LEVINSON, B. (1997) Masculinities and femininities in the Mexican secundaria: notes toward an institutional practice of gender equity, paper delivered at the 1997 meeting of the Latin American Studies Association, Guadalajara, Jalisco, Mexico, April 17.

LEVINSON, B. (1999) "Una etapa siempre dificil": concepts of adolescence and secondary education in Mexico, Comparative Education Review, 43, 2, May, pp. 129-161.

LOMNITZ, L. and PEREZ-LIZAUR, M. (1987) A Mexican Elite Family, 1820-1980 (Princeton, Princeton University Press).

MARTIN, C. (1985) Hegemonía, cultura y educación: atisbos sobre el desarrollo de la escuela, Revista Encuentro, 9, 1, pp. 17-48.

MARTIN, C. (1990a) "To hold ones own in the world": issues in the educational culture of urban working class families in West Mexico, Compare, 20, 2, pp. 115-138.

MARTIN, C. (1990b) Lo ideal y lo real en la educación primaria urbana: dos casos de la zona metropolitana de Guadalajara, in: DE LA PEÑA, G., DURAN, J.M., ESCOBAR, A. \& GARCIA DE ALBA, J. (Eds) Crisis, Conflicto y Sobrevivencia: Estudios sobre la Sociedad Urbana en México (Guadalajara, Universidad de Guadalajara/Centro de Investigaciones y Estudios Superiores en Antropología Social (CIESAS)).

MARTIN, C. (1992) The dynamics of school relations on the urban periphery of Guadalajara, Western Mexico, European Review of Latin American and Caribbean Studies, 53, December, pp. 61-81.

MARTIN, C. (1993a) The "shadow economy" of local school management in contemporary West Mexico, Bulletin of Latin American Research, 12, 2, pp. 171-188.

MARTIN, C. (1993b) On the cheap: educational modernization at school level in Mexico, in: ALLSOP, T. and BROCK, C. (Eds) Key Issues in Educational Development (Cambridge, Cambridge University Press/Triangle Books).

MARTIN, C. La modernización educativa en México, mimeo.

MARTIN, C. (1994) Let the young birds fly: schooling, work and emancipation in rural west Mexico, Compare, 24, 3, pp. 259-276.

MARTIN, C. (1996a) Personal and social development in post-compulsory education in the UK and Mexico, Compare, 26, 2, June, pp. 133-152.

MARTIN, C. (1996b) Economic strategies and moral principles in the survival of poor households in Mexico. An urban and rural comparison, Bulletin of Latin American Research, 15, 2, pp. 193-210.

MARTIN, C. (1998a) La Educación Primaria en Tiempos de Austeridad (Mexico, Universidad de Guadalajara / The British Council). 
MARTIN, C. (1998b) More for less: the Mexican cult of educational efficiency and its consequences at school level, in BUCHERT, L. (Ed.) Education Reform in the South in the 1990s (Paris, UNESCO).

MARTIN, C. (1999) World Bank School Study, Phase Two: Background Paper, mimeo.

MARTIN, C. with Solórzano, C. (2000) Mass education, privatization, compensation and diversification: issues on the future of public education in Mexico, mimeo.

MORALES-GOMEZ, D. and TORRES, C. (1990) The State, Corporatist Politics, and Educational Policy Making in Mexico (New York, Praeger).

MORLEY, L. and RASSOOL, N. (1999) School Effectiveness: Fracturing the Discourse (London, The Falmer Press).

MURGATROYD, S.J. (1977) Pupil perceptions of counselling: a case study', British Journal of Guidance and Counselling, 5, 1, pp. 73-78.

MUUSS, R.E. (1997) Teorías de la Adolescencia (México, Paidós).

NIAS, J. (1997) Would schools improve if teachers cared less?, Education, 3, 13.

NODDINGS, N. (1992) The Challenge to Care in Schools (New York, Teachers' College Press).

ORNELAS, C. (2001) Equidad, educación comunitaria y programas compensatorios, in: ORNELAS, C. (Ed.) Investigación y Política Educativas: Ensayos en Honor de Pablo Latapí (México, Editorial Santillana).

PALAFOX, J., PRAWDA, J. and VELEZ, E. (1994) Primary school quality in Mexico, Comparative Education Review, 38, 2, pp. 167-180.

PRO HABITAT (2000 http:// iisd.ca/measure/cereport.htm) Metrozone Guadalajara, Mexico: Project Report.

QUIROZ, R. (1990) Los nuevos planes y programas no resuelven los problemas actuales de la secundaria, Documento DIE No.18, Departamento de Investigaciones Educativas/Centro de Investigación y de Estudios Avanzados del Instituto Politécnico Nacional, México D.F., pp. 47-49.

QUIROZ, R. (1995) Los cambios de 1993 en los planes y programas de estudio en la educación secundaria, Documento DIE No. 40, Departamento de Investigaciones Educativas/Centro de Investigación y de Estudios Avanzados del Instituto Politécnico Nacional, México D.F.

RAMIREZ, M. (1990) Migración y marginalidad en Guadalajara: el caso de Lomas de Tabachines, in: DE LA PEÑA, G., DURAN, J.M., ESCOBAR, A. \& GARCIA DE ALBA, J. (Eds) Crisis, Conflicto y Sobrevivencia: Estudios sobre la Sociedad Urbana en México (Guadalajara, Universidad de Guadalajara/Centro de Investigaciones y Estudios Superiores en Antropología Social (CIESAS)).

REIMERS, F. (2001) Educación, exclusión y justicia social en América Latina, in: ORNELAS, C. (Ed.) Investigación y Política Educativas: Ensayos en Honor de Pablo Latapí (México, Editorial Santillana).

ROCKWELL, E. (1990) Valores en la educación mexicana, in Documento DIE No.18, Departamento de Investigaciones Educativas/Centro de Investigación y de Estudios Avanzados del Instituto Politécnico Nacional, México D.F., pp. 1-10.

ROSAS, R. (2000) Dinámica de las redes sociales y de apoyo emocional en hogares pobres urbanos: el caso de México, paper presented at the 2000 meeting of the Latin American Studies Association, Miami, 16-18 March.

SAMMONS, P. (1999) School effectiveness: Coming of Age in the Twenty-First Century (Lisse, Swets and Zeitlinger B.V.).

SANCHEZ ESCOBEDO, P. A. and PINTO SOSA, J.E. (1995) Incidencia de los problemas que afectan a los ninos de primaria en Yucatan, Mexico, paper presented at the III Congreso de Educación Educativa, Mexico D.F..

SANDOVAL, E. (1993) Escuela secundaria y modernización educativa, Cero en Conducta, 8, 35, October, pp. 4-11.

SCHMELKES, S. (1992) Hacia una mejor calidad de nuestras escuelas (SEP, Mexico D.F.).

SCHMELKES, S. (1999) Teaching and schools in Mexico, mimeo. 
SCHUTZ, A. (1932/1972) The Phenomenology of the Social World (London, Heinemann Educational Books).

SCHUTZ, A. and LUCKMANN, T. (1973) The Structures of the Life World (London, Heinemann). SCINCE (1995) Reporte Por AGEB de la Unidad Geográfica E0980001 (Mexico, INEGI Sistema Para La Consulta De Información Censal).

SEP (1993) Plan y Programas de Estudio 1993, Educación Básica: Secundaria (Mexico, SEP).

SEP/IMJ (2000) Jóvenes e Instituciones en México (México, Secretaría de Educación Pública/Instituto Mexicano de la Juventud).

SNTE (1994) Propuestas para asegurar la calidad de la educacion pública, paper presented at the I Congreso Nacional de Educación, Mexico, Sindicato Nacional de Trabajadores de la Educación.

STIGLER, J. (1991) Individuals, institutions and academic achievement, in: Bourdieu, P. and Coleman, J. (Eds) Social Theory for a Changing Society (Boulder, Westview Press).

THOMPSON, A. (1997) Surrogate family values: the refeminisation of teaching, Educational Theory, 47, 3, pp. 315-339.

TRUEBA, H. and ZOU, Y. (1998) Introduction, in: ZOU, Y. and TRUEBA, H. (Eds) Ethnic Identity and Power: Cultural Contexts of Political Action in School and Society (Albany, State University of New York).

VAUGHAN, M. (1982) The State, Education, and Social Class in Mexico, 1880-1928 (Illinois, Northern Illinois University Press).

WILLIS, P. (1977) Learning to Labour (Farnborough, Saxon House).

WORLD BANK (1999) World Development Report 1998/99: Knowledge for Development (New York, Oxford University Press).

Www.sep.gob.mx 